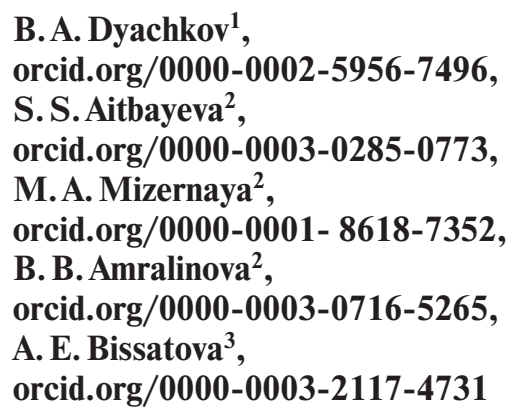

1 - LLP "Altaiskiy Geologic-Ecological Institute”, Ust-Kamenogorsk, the Republic of Kazakhstan, e-mail: bdyachkov@ $\underline{\text { mail.ru }}$

2 - D. Serikbayev East Kazakhstan State Technical University, Ust-Kamenogorsk, the Republic of Kazakhstan, e-mail: AitbayevaSS@mail.ru

3 - "LLP "GEOS", Ust-Kamenogorsk, the Republic of Kazakhstan

\title{
NEW DATA ON NON-TRADITIONAL TYPES OF EAST KAZAKHSTAN RARE METAL ORE
}

Purpose. Studying the patterns of formation and assessing the prospects of non-traditional types of rare-metal mineralization in East Kazakhstan.

Methodology. Analysis of literary and funds materials; conducting field research on typical objects; sample selection; conducting of isotope research on typical objects; ICP-MS - Agilent 7500cx mass spectrometric analysis, microprobe analysis using a JSM 6390LV scanning electron microscope with an energy dispersive attachment, X-ray diffraction analysis - CPB-1M, silicate chemical analysis.

Findings. A new non-traditional "non-pegmatite" type of rare-metal mineralization of predominantly lithium specialization associated with small intrusions and dikes of the kunush complex and albitized and greisenized granites (apogranites) is substantiated.

Originality. A geological and genetic model of rare metal ore formation has been developed, reflecting the superimposition of rare metals $\left(\mathrm{Sn}, \mathrm{W}, \mathrm{Li}\right.$, etc.) on earlier small intrusions of plagiogranites of the kunush complex $\left(\mathrm{C}_{3}\right)$, susceptible to contactmetasomatic transformations under the influence of rare-metal granites of the Kalba complex $\left(\mathrm{P}_{1}\right)$. The prospects of an independent "non-pegmatite" type of tin-tantalum-lithium mineralization are substantiated.

Practical value. The results of the research are aimed at strengthening the mineral resource base as an additional source of rare metals for existing enterprises in East Kazakhstan.

Keywords: East Kazakhstan, granitoid belts, adakites, deposits, rare metals, Kalba-Narymskaya zone

Introduction. The research relevance is defined by constantly growing demand of the world market in rare and rare earth metals ( $\mathrm{Ta}, \mathrm{Nb}, \mathrm{Be}, \mathrm{TR}$, and others). As the east of $\mathrm{Ka}$ zakhstan is the center of metallurgy, it is very important to regenerate rare metal industry for providing enterprises with raw materials. Kalba Narym metallogenic zone refers to the largest rare metal structures of Kazakhstan. The deposits of rare metal pegmatites (Yubileinoye, Belaya Gora) were actively developed here in previous years as well as many greisen-quartz and hydrothermal stannum-tungsten deposits (Palatsy, Cherdoyak, and others). Mining operations were stopped in 1994, the deposits were suspended, as for the new objects of practical significance, they have not been discovered yet.

Scientific-research work that has been carried out in recent years shows that additional resources of rare metals can be "extrapegmatite" types of rare metal ore ( $\mathrm{Sn}, \mathrm{Ta}, \mathrm{Li})$, connected with rare metal granites (Karasu, Novo-Akhmirovskoye, Apogranitnoye, Shuruk, and others), by analogy with albitized spodumene granite-porphyrites of the Gorny Altay with complex lithium-tantalum ore (Alakh deposit) [1, 2].

Distinguishing of a stand-alone type of rare metal-pegmatite ores $(\mathrm{Li}, \mathrm{Ta}, \mathrm{Nb}$, etc.) and greisen-quartz ore $(\mathrm{Sn}, \mathrm{W})$ is of scientific and practical significance. It is superimposed on earlier dyke minor intrusions of Kunush complex $\left(\mathrm{C}_{3}\right)$ widely developed in Kalba Narym zone. It can be also helpful to reevaluate perspectives of some pegmatite deposits and ore occurrence for complex stannum-tantalum-lithium raw materials. Evaluation of Mirolyubovsky complex $\left(\mathrm{P}_{2}\right)$ ongonite dykes ore content is also noteworthy.

General characteristic of the researched region. The territory of East Kazakhstan is comprised into Central Asian mobile belt $(\mathrm{CAB})$. CAB Hercynides form belt structures of

(C) Dyachkov B.A., Aitbayeva S. S., Mizernaya M.A., Amralinova B. B., Bissatova A. E., 2020 north-west course in the east of Kazakhstan (from the northeast to the south-west): the Rudny Altai, Irtysh shear zone, Kalba Narym zone, West Kalba and Zharma-Saur [3]. Caledonites of the Gorny Altai (in the north-east) and ChingizTarbagatai (in the south-west) are referred to flank structures.

The main regularity is in belt location of ore objects, as linear north-west ore belts: copper-polymetallic (Rudny Altai), rare metal (Kalba Narym), and multi-metal (Zharma Saur) $[4,5]$.

Rare metal deposits were formed mainly during Late Hercynian stage of post-collision (orogenic) intraplate activization that went along with strong granitoid magmatism that is typical for many regions of Central Asia. Spatially they are located in large granitoid belts of considerable length (up to 800 $\mathrm{km}$ ), concentrated in places of tectonically low coherence and they are controlled by the system of deep faults [3, 5].

The Kalba Narym granitoid belt is basic rare metal structure of the region. Its structural-metallogenic model reflects connection of ore-magmatic systems with depth zones of earth crust and upper. Cycle-oriented development of tectonic and magmatic processes affected succession of geological formations: gabbro diorite formation (Karabiryuksky complex $\mathrm{C}_{2-3}$ ) and granodiorite-plagiogranite formations (Kunush complex $\mathrm{C}_{3}$ ) of collision type; granite formation (Kalba complex $\mathrm{P}_{1}$ ), leucocratic formation (Monastyrsky complex $\mathrm{P}_{2}$ ) and gabbrodiabase-granite-porphyrite formation (Mirolyubovsky complex $\mathrm{P}_{2}$ ) of post-collision (orogenic) type [5].

The article considers regularities of formation and location, and practical significance of rare metal deposits of different geologic-genetic types.

Characteristic of rare metal pegmatites deposits. This geological-industrial type is the leading source of $\mathrm{Ta}, \mathrm{Nb}, \mathrm{Be}, \mathrm{Li}$, Cs. Sn within Kalba Narym zone [3, 5]. The deposits were formed in Central Kalba tectonic block. The known ore fields (Ognevsk-Bakennoye, Asu-Bulak, Belagorsk-Baimurzins- 
koye, and others) are controlled by the system of rejuvenated regional EW faults, and industrial deposits (Bakennoye, Yubileinoye, Belaya Gora) are concentrated in their branch structures. Positional and genetic connection of rare-metalpegmatite ore with the $1^{s t}$ phase medium-coarse grained porphyraceous biotite granites of Kalba complex has been defined for the complex of new geological-structural, ore-petrological and mineralogical-geochemical data $[3,6]$.

Ore-hosting rocks are represented by granitoids of normal petrochemical series of contaminated habitus (granites, granodiorites, and others), plumasite agpaite, and moderate basicity compared with the first type of pegmatite bearing granite systems according to S. M. Beskin, Yu. B. Marin [7]. According to the new results of mass spectrometry, content of rare earth content in the $1^{\text {st }}$ phase granites is $80.74 \mathrm{~g} / \mathrm{t}$ with predominance of light elements group over the group of heavy elements $(5: 1)$. Their geochemical differentiation into rare alkalies is emphasized. The rare alkalies are $(\mathrm{Li}, \mathrm{Rb}, \mathrm{Cs}=429.2 \mathrm{~g} / \mathrm{t})$ and $\mathrm{Sn}(14.6 \mathrm{~g} / \mathrm{t})$ with the concentration of rare elements in biotite $(\mathrm{g} / \mathrm{t})$ : Ta (17.97), Nb (124.5), Li (up to 1521), Rb (up to 1430), Sn (23.73-90.70). Accompanying elements are $\mathrm{Cu}$ (48.02), Zn (105.01), Pb (80.90), Sb (1.51), Ag (0.72), Au (0.29), and others.

Pegmatite veins are characterized by intensive microclinization, albitization, greysening, and spodumenization processes with further concentration of $\mathrm{Ta}, \mathrm{Nb}, \mathrm{Be}, \mathrm{Li}$ and other elements from simple aplite-pegmatites to more productive spodumene-containing and caesium-bearing mineral components resulted in formation of pay-ores. The following minerals are indicators of rare metal pegmatite formation: albite, cleavelandite, green muscovite, lepidolite, colored tourmaline, pollucite, amblygonite and some others. Basic ore minerals are: tantalite- columbite, beryl, spodumene, pollucite, and cassiterite. According to peculiarities of material composition and presence of unique minerals, Kalba pegmatitesare are compared with such foreign deposits as Koktogay (China), Bikita (Zimbabwe), Bernik-Lake (Canada) and others $[8,9]$.

Pegmatite deposits with superimposed ores. This group includes small pegmatite deposits of Karagoin-Saryozeksk ore zone, where rare metal ore $(\mathrm{Ta}, \mathrm{Nb}, \mathrm{Be}, \mathrm{Li})$ is superimposed on dyke-shaped plagiogranites of Kunush complex $\left(\mathrm{C}_{3}\right)$ located in exocontacts of Kalba complex $\mathrm{P}_{1}$ granitoids (Medvedka, Tochka, Novo-Saryozek, Aldai and others). Geological-genetic model of rare metal pegmatite formation reflects contact-metasomatic reconversion of anterior plagiogranites of Kunush complex $\left(\mathrm{C}_{3}\right)$ under the influence of crystallized granite massif of Kalba complex $\left(\mathrm{P}_{1}\right)$ resulted in superimposed ore-bearing fluid flows $\left(\mathrm{H}_{2} \mathrm{O}, \mathrm{F}, \mathrm{B}, \mathrm{Cl}, \mathrm{Ta}, \mathrm{Be}, \mathrm{Li}\right.$, and others) and in ladder-type pegmatite veins formation. According to S. V. Lugov, G. N. Shcherba, F. N. Shakhov plagiogranites are considered as physical-chemical environment that is tectonically developed and favorable for deposition and concentration of ore matter.

Medvedka deposit is a typical object with rare metal ore superimposed on plagiogranites of Kunish complex. According to the data provided by P.I.Sinishin, A. R. Butko, there are three plate-shaped bodies of medium-grained biotite plagioranites (480-1100 $\mathrm{m}$ long, and 40-120 m thick) where there are ladder-type veins of microcline-albite pegmatites with rare metal ore ( $\mathrm{Ta}, \mathrm{Nb}, \mathrm{Be}, \mathrm{Li}, \mathrm{Sn})$. Ore-hosting plagiogranites are subjected to gneiss metamorphosis, cataclasis and characterized by flat-lying fracture set that is favorable to location of pegmatite veins that do not extend beyond the boundaries of an intrusive body (Fig. 1).

Plagiogranites are rocks of light-grey colour, that have equigranular texture and are characterized by consistent quantitative-mineral composition (\%): plagioclase 59-62 (No. 8$35)$, quartz 26-28, potassium feldspar 2-4, biotite 6.5 and accessories $0.3-0.6 \%$. There is also hypersthene $(6.1 \%)$ in the norm. They correspond to eutectoid facie of granitoids ac-
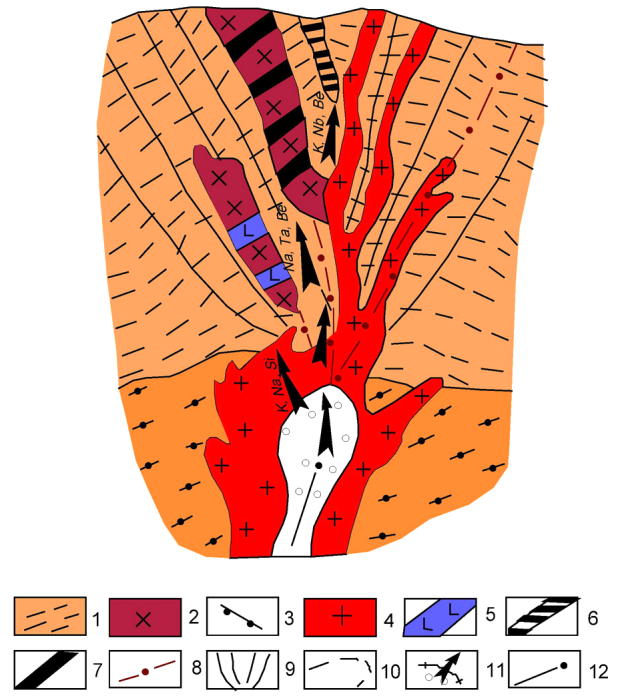

Fig. 1. Geological-genetic model of rare-metal pegmatites on the example of Medvedka deposit, according to geological exploration materials:

1 - aleurolites with sand rock layers (Takyr suite); 2 - plagiogranites; 3 - plagiogranite-porphyrites, granite-porphyrites of Kunush complex; 4-7 - Kalba complex (4-medium-coarse grained biotite granites of the I phase; 5 - oligoclase-microcline barren pegmatites; 6 - block microcline pegmatites; 7 - rare metal microcline-albite and albite pegmatites); 8 - faults; 9 - excessive fissuring zones; 10 - supposed ring structure; 11 - direction of fluid flows displacement; 12 - ore conduit

cording to the type of crystallization. According to petrochemical data they are rocks of normal series, low total base number $\left(\mathrm{Na}_{2} \mathrm{O}+\mathrm{K}_{2} \mathrm{O}=6.36\right.$ mass. \% $)$ when natrium is significantly predominant over potassium and there is high alumina $\left(\mathrm{al}^{\prime}=\right.$ $=5.74)$. On the diagram $\mathrm{K}_{2} \mathrm{O}-\mathrm{SiO}_{2}$ plagiogranites belong to low-potassium calci-alkalic series and are located on the boundary with tholeitic series [6, 7].

According to geochemical data, lanthanides predominate over heavy elements in plagiogranites among rare earth. Besides there is low content of Sm $1.85 \mathrm{~g} / \mathrm{t}, \mathrm{Yb} 0.52 \mathrm{~g} / \mathrm{t}$ and $\mathrm{Y}$ $6.2 \mathrm{~g} / \mathrm{t}, \mathrm{La} / \mathrm{Yb}$ ratio is 16 times higher.

Plagiogranites enrichment is of special significance $\mathrm{Sr}$ (up to $583-815 \mathrm{~g} / \mathrm{t}$ ), and isotopic $\mathrm{Rb}^{87} / \mathrm{Sr}^{86}$ ratio in them is very low $(0.14827-0.23639)$. Plagiogranites belong to $x+\varepsilon \mathrm{Nd}$ type [20] according to their isotopic-geochemical characteristics [8]. Thus, plagiogranites of Kunush complex enriched with aluminum oxide, natrium alkalinity and with low content of rare earth according to geochemical indicators are a particular adakite group of rocks in evolution range of Kalba-Narym zone granitoids $[9,10]$. Their origin is possible due to degradation melting of basites $\left(\mathrm{P}=15 \mathrm{kbar}, \mathrm{T}=950{ }^{\circ} \mathrm{C}\right)[11,12,13]$.

According to the new geochronological definitions $\mathrm{U}-\mathrm{Pb}$ isotopic method for zircons, the age of Tochka massif plagiogranites has been defined $(299 \pm 2.3$ million years $)$ as well as that of Zhilandy (306.7 million years) [6, 10], that is consistent with absolute data of $\mathrm{K}-\mathrm{Ar}$ method of previous years (305 mil. years according to 20 analyses) for granitoids of Kunush complex.

According to ICP-MS results, the content of rare elements ( $\mathrm{Ta}, \mathrm{Nb}, \mathrm{Be}, \mathrm{Li}, \mathrm{Sn}$ ) in plagiogranites is close to Kalba complex granitoids of the $1^{\text {st }}$ phase, but the value $\Sigma=\mathrm{Li}+\mathrm{Rb}+\mathrm{Cs}$ $(231.8 \mathrm{~g} / \mathrm{t})$ is lower. There is also weight content $(\mathrm{g} / \mathrm{t}): \mathrm{Sb}$ (3.29), Ag (2.04), Au (0.23), Bi (8.80), Pt (0.03), Pd (0.81), Re (0.02), U (3.29).

Ore was formed under tectonic pressure that contributed to opening of flat-lying fracture structures for penetrating of pegmatite forming solution and formation of microcline-muscovite and microcline-albite pegmatites. Content of ore-forming solutions is fluorine-chloride (when content is $\mathrm{K}^{+}=24.2$ 
and $\mathrm{Na}^{+}=21.8 \%$ ). The sources of ore substance were unopened domes of Kalba granites and probably, enclosing plagiogranites. Ore bodies extending 480-1100 $\mathrm{m}$ long and 40$120 \mathrm{~m}$ wide are evident, north-east dip is $<60-70^{\circ}$. The largest veins are Moshchnaya, Berillovaya, Maiskaya, Obnazhennaya, and others.

Ore indicators are albite and muscovite, which is transparent of light-green color that contains impurities $(\mathrm{g} / \mathrm{t})$ : Ta (233.7), Nb (380.8), Be (36.6), Li (1101), Rb (3614), Cs (241.4), Sn (429.3). Micro-inclusions of tantalite-columbite and cassiterite have been found in muscovite during analysis on the scanning microscope, their size is $1-2 \mathrm{mkm}$.

Beryl is found in block quartz-microcline pegmatite forming crystals up to $5 \mathrm{~cm}$ on the macroaxis and up to $4 \mathrm{~cm}$ in diameter.

Tantalite-columbite is represented by sorbitic variety $(\mathrm{Ta}-$ $98560, \mathrm{Nb}-152100 \mathrm{~g} / \mathrm{t})$, contains impurities $(\mathrm{g} / \mathrm{t}): \mathrm{Be}(26.52), \mathrm{Sn}$ (752.1), W (2218), $\sum \mathrm{Li}+\mathrm{Rb}+\mathrm{Cs}$ (66.94). High $\mathrm{Ta}_{2} \mathrm{O}_{5}$ content is observed in albite-spodumene pegmatites $(0.120 \%)$ and greisens of quartz-muscovite composition $(0.266 \%)$, the average value of the deposit is $0.007-0.008 \%$. As for metal reserves $\left(\mathrm{Ta}_{2} \mathrm{O}_{5}-277 \mathrm{t}\right.$, $\mathrm{BeO}-2276 \mathrm{t}$ ), this is a small object of reserve type.

Rare metal objects of unconventional type. Novo-Akhmirovskoye deposit is located at the boundary of Kalba-Narym and Irtysh tectonic zones not far from Ust-Kamenogorsk. It is the representative of $\mathrm{Sn}-\mathrm{Ta}-\mathrm{Li}$ ore unconventional type that is connected with rare metal granites (apograntes). It is represented by stock-shaped body of topaz, zinwaldite-lepidolite granites and dykes of ongonites $\left(\mathrm{P}_{1}\right)$ [2]. According to materials provided by V. I. Maslov, B. M. Lutskoi, V. S. Sergienko, the older sedimentary-metamorphic rock mass of Late Proterozoic - Early Paleozoic age is developed in Irtysh block. The remaining territory is characterized by bassets of Kystyv-Kurchum $\left(\mathrm{D}_{2} \mathrm{gv}\right)$ and Takyr suites that are considerably overlapped with Mesozoic and Cenozoic loose sediments cover [3].

Dikes of aplitic granites and aplite-pegmatites containing brownish-black spots of $\mathrm{Li}, \mathrm{Fe}, \mathrm{Mn}$ phosphates are developed in endo-contact areas. Aplite-pegmatites have coarse-grained structure, sharp or indistinct contacts with granites and contain inclusions of arrow-head feldspar (Fig. 2).

According to geophysics and well-drilling data, granites with unchanged material composition are observed until the depth of 300-374 m and they form stock-shaped or chimney body at the cross section. According to the data of geophysical materials interpretation, it is supposed that Novo-Akhmirovsky stock is apophyse or large brow of granite rock mass more than $1.5 \mathrm{~km}$ deep [3].

Mineral composition of granites includes quartz (30$40 \%)$, albite (25-40\%), microcline (15-35\%), zinwaldite-lepidolite $(10 \%)$. Accessory minerals are topaz (up to $5 \%$ ), lithium muscovite, fluor apatite, cassiterite and amblygonite [3]

The results of mineral composition microprobe analysis showed that lithium mica changes from lepidolite to zinwaldite and polylithionite in its compound. Average content of mica is the following: $\mathrm{Li}_{2} \mathrm{O}(2.5-4.45 \%), \mathrm{F}(3.04-4.4 \%), \mathrm{Ta}_{2} \mathrm{O}_{5}$ (up to 0.005 ), $\mathrm{Nb}_{2} \mathrm{O}_{5}$ (up to $0.025 \%$ ) and $\mathrm{Sn}(0.028-0.04 \%$ ).

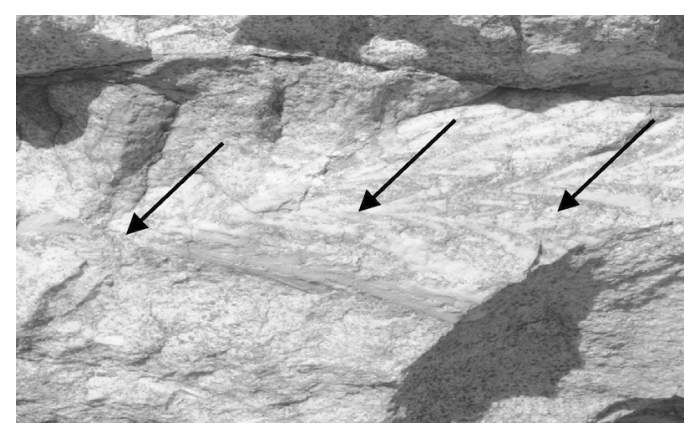

Fig. 2. Aplite-pegmatite vein
There are two topaz generations: primary topaz is crystal shaped and a few millimeters in size, subsequent topaz is in the form of irregular grains in albite and lepidolite associations.

Cassiterite forms separate small grains or attachments (1-2 mm) of zonal colour from brown to black, and it is limited to albitized fields. It was analyzed on the microprobe CAMEBAX (analytic O.N. Maiorova) and the content of $\mathrm{Ta}_{2} \mathrm{O}_{5} 0.98$ mas. $\%$ was defined [3]. According to quantitative spectral analysis, this content is up to $2.8 \%$ (VNIItsvetmet).

According to their material composition characteristics, albitized granites of Novo-Akgmirovo area are compared with typical rare metal granites of plumasite series that are considerably enriched with $\mathrm{Li}, \mathrm{Rb}, \mathrm{Sn}, \mathrm{Ta}$.

As drilling shows, there is a tendency of rare metal content increase in holes up to $300 \mathrm{~m}$ deep (mas. \%): $\mathrm{Li}_{2} \mathrm{O}(0.15-$ $0.17 \%), \mathrm{Sn}(0.045-0.15 \%), \mathrm{Ta}_{2} \mathrm{O}_{5}(0.005-0.095 \%)$ [3].

The authors of the paper further examined enclosing rocks and ore-bearing albitized granites, and also carried out mass spectrometric analyses (ICP-MS). The content of rare earth from ceric group is increased in Kystyv-Kurchum suite, as well as $\mathrm{Zr}(310.2 \mathrm{~g} / \mathrm{t}), \operatorname{Sr}(173.9 \mathrm{~g} / \mathrm{t}), \mathrm{Ba}(392 \mathrm{~g} / \mathrm{t}), \operatorname{Ti}(5110 \mathrm{~g} / \mathrm{t})$. The anomalies of $\mathrm{Li}, \mathrm{Rb}, \mathrm{Cs}$ and $\mathrm{Nb}$ have been identified among rare metals, which emphasizes enrichment of trans-intrusive zone with rare alkali elements. Veined granites are enriched $(\mathrm{g} / \mathrm{t}): \mathrm{Li}(753), \mathrm{Rb}$ (773), there is high content of $\mathrm{Ta}(6.57), \mathrm{Nb}$ (37.16), Sn (14.62) in them. The anomaly of $\mathrm{Rb}(656.1)$ and $\mathrm{Li}$ (311.4), Nb (20.77) and $\mathrm{Sn}$ (24.2) content is distinguished in coarse-grained pegmatites.

Ceric group of rare earth elements $(104.4 \mathrm{~g} / \mathrm{t})$ is predominant in albitized granites. $\mathrm{Li}-\mathrm{Rb}$ geochemical specialization of altered granites with weight values $\mathrm{Ta}, \mathrm{Nb}, \mathrm{Be}, \mathrm{Sn}$ is underlined (Table 1). Generally, the laboratory research proves rare metal specialization of Novo-Akhmirovo area albitized granites on $\mathrm{Li}-\mathrm{Rb}$ and foreign-metal impurities - $\mathrm{Ta}, \mathrm{Nb}, \mathrm{Sn}$.

According to V. I. Maslov's data, inferred resources of Novo-Akhmirovskoye deposit are reasonably sufficient. According to its ore type, the considered object is similar to Losevskoye deposit (North Kazakhstan) and Alakh deposit in the Gorny Altai $[1,14]$. The following objects also belong to this ore type: Karasu deposit, and prospecting sites Apogranitny, Malo-Chernovinsky, Shuruk, Muncha, Tortkamak II and others and they are recommended for evaluation work.

Cherdoyak deposit is in Narym ore area of Kalba-Narym zone, $180 \mathrm{~km}$ from Ust-Kamenogorsk. It is typical deposit of stannum-tungsten ore superimposed on plagiogranites of $\mathrm{Ku}$ nush complex. It was discovered by P. K. Kalik and further was examined by P. K. Korovin, N. N. Budanov, T.A. Minenko, G. N. Shcherba, B. M. Rudenko and other researchers. The deposit was formed on west exocontact of Narym granitoid massif $\left(\mathrm{P}_{1}\right)$. Its influence on the older Kunush massif of plagiogranites $\left(\mathrm{C}_{3}\right)$ reflected in excessive fissuring, cataclasis, crumpling, graphitization and silicification.

It caused breaking Kunush complex plagiogranites integrity and further penetration in low coherence places of orebearing solutions. It contributed to stannum-tungsten ore concentration that is genetically connected with Perm granites, and to formation of stockwork- and vein-shaped ore bodies that formed combined veined-stockwork structure of the deposit. Ore bodies directly localize in plate-like dyke of plagiogranites (the length is $1000 \mathrm{~m}$, the width is $120-200 \mathrm{~m}$, north-east dip angle is 65-700) (Fig. 3) [15].

Plagiogranites partially or completely recrystallize and their ground mass is fine-grained. Chemical composition of plagiogranites is oversaturated with $\mathrm{SiO}_{2}(Q=+27.7)$, alumina $\left(a^{1}=43\right)$ and moderately rich with alkalies $(a: c=4.7)$. As for their alkalinity nature $\left(\mathrm{Na}_{2} \mathrm{O}: \mathrm{K}_{2} \mathrm{O}=3.4\right)$ it is typical sodium low-plumasite series of granitoids with low total ferruginosity $(t=0.63)$ and high calcium $(c=2.7)$. Plagiogranites $\mathrm{Si}, \mathrm{Ca}, \mathrm{K}$ loss and $\mathrm{Mg}, \mathrm{B}, \mathrm{F}, \mathrm{C}, \mathrm{Sn}$ and $\mathrm{W}$ gain is associated with greysening and graphitization. Ore bodies are represented by quartz veins and stockworks. Basic ore minerals are cassiterite, schee- 
Content of rare elements in albitized granites

\begin{tabular}{|l|c|c|c|c|c|c|c|c|c|}
\hline \multicolumn{1}{|c|}{ Rock No. } & $\mathrm{Ta}$ & $\mathrm{Nb}$ & $\mathrm{Be}$ & $\mathrm{Li}$ & $\mathrm{Rb}$ & $\mathrm{Cs}$ & $\mathrm{Sn}$ & $\mathrm{W}$ & Mo \\
\hline HA-4 & 6.09 & 36.81 & 4.83 & 732.00 & 1124.0 & 50.92 & 9.35 & 1.95 & 0.88 \\
\hline HA-5 & 4.43 & 27.06 & 5.09 & 652.00 & 664.3 & 37.88 & 10.05 & 2.63 & 0.63 \\
\hline HA-6 & 1.10 & 10.89 & 4.83 & 869.00 & 613.3 & 45.37 & 12.94 & 2.21 & 0.73 \\
\hline HA-7 & 9.81 & 52.22 & 4.69 & 1147.00 & 1070.0 & 40.01 & 13.08 & 2.01 & 0.86 \\
\hline HA-14 & 7.60 & 56.46 & 7.48 & 1032.00 & 840.2 & 37.01 & 20.29 & 2.53 & 1.34 \\
\hline HA-15 & 1.35 & 13.76 & 7.60 & 970.00 & 964.4 & 41.88 & 32.00 & 2.43 & 1.40 \\
\hline HA-16 & 6.00 & 57.42 & 8.40 & 921.00 & 785.1 & 33.07 & 12.45 & 5.27 & 3.11 \\
\hline HA-19 & 16.16 & 195.20 & 13.31 & 2152.00 & 1413.0 & 48.07 & 12.82 & 2.04 & 68.77 \\
\hline average & 6.56 & 56.22 & 7.02 & 1059.37 & 934.28 & 41.77 & 15.37 & 2.63 & 9.71 \\
\hline
\end{tabular}
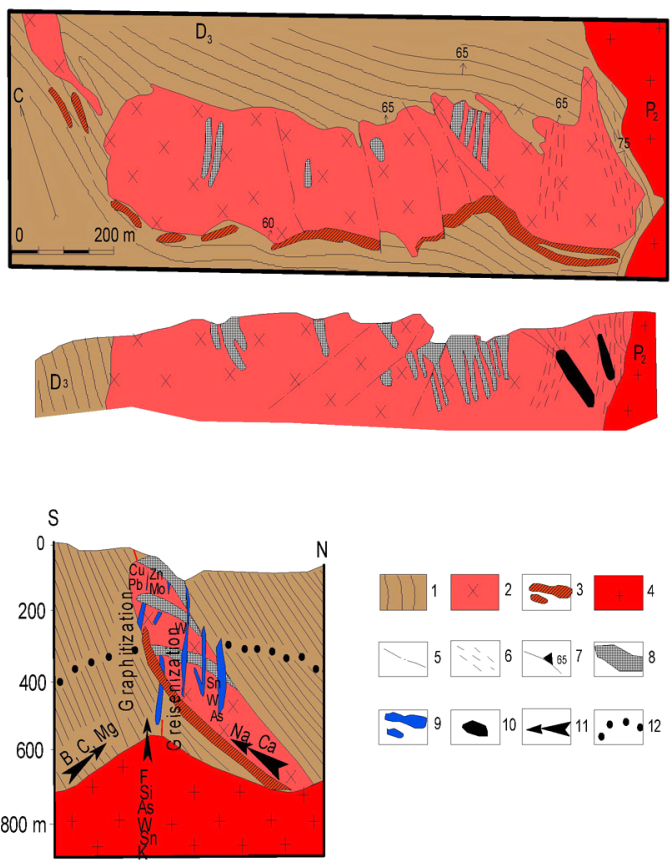

Fig. 3. Geologic structure of stannum-tungsten Cherdoyak deposit:

1 - sandstone-aleurolitic deposits of Takyr suite, $D_{3} ; 2$ - plagiogranites; 3 - quartz veins, $C_{3} ; 4$ - I phase granites; 5 - II phase granites of Kalba complex, $P_{1} ; 6$-faults; 7 -foliation, shear; 8 strike and dip lamination; 9 - anticipated ore bodies; 10 - plagiogranite- porphyrites of Kunush complex; 11 - directions of solutions movement; 12 - erosional truncation boundary

lite, arsenopyrite; auxiliary ore minerals are pyrite, chalcopyrite, galena, and others [15].

Arsenopyrite is a typical ore mineral of greisen and less of quartz veins. They form well-edged crystals, twins, and crystaljams and their size is from $1-2 \mathrm{~mm}$ up to $2-3 \mathrm{~cm}$. Crystal lattice parameters were defined by X-ray structure analysis: $a\left(A_{0}\right)=$ $=9.528 ; b\left(A_{0}\right)=5.546 ; c\left(A_{0}\right)=6.529$. They are characterized by high content of light rare earth $(276.74 \mathrm{~g} / \mathrm{t})$ and increase in chalcophylic elements (g/t): $\mathrm{Cu}$ (378.0), Pb (439.7), Zn (174.7), Bi (100.4). Besides, precious elements were identified $(\mathrm{g} / \mathrm{t})$ : $\mathrm{Sn}$ (174.9), Ta (11.79), impurity In (1.09 g/t). Increased content of $\mathrm{Ni}(815), \mathrm{Co}(323.5)$ and $\mathrm{Cr}(664.0 \mathrm{~g} / \mathrm{t})$ was determined.

Scheelite in greisen forms bunches (their size is up to $16 \mathrm{~cm}$ in diameter) contains tourmaline needles and impurities of $\mathrm{Sn}$ $1 \%$ and As $0.2-0.4 \%$. According to mass spectrometric analyses, it is enriched with rare earth $(\Sigma=242.4 \mathrm{~g} / \mathrm{t})$ and predominant lantoid group (g/t): Ce (121), Nd (110), La (39). Siderophile elements are mainly represented by Fe $(6870 \mathrm{~g} / \mathrm{t})$, Ti
(462), Mn (430), Ni (88). The values of B (105.5 g/t), $\mathrm{Zr}$ (39.2), Y (24.6) and Th (6.7) are increased. For the first time anomalous concentration of $\mathrm{Hg}(3079 \mathrm{~g} / \mathrm{t})$ and $\mathrm{Re}(4.47-$ $7.37 \mathrm{~g} / \mathrm{t}$ ) has been determined.

Cassiterite in greisen is characterized by small impregnation (1 $\mathrm{mm}-1-2 \mathrm{~cm}$ in diameter) and forms bunches and inclusions of irregular shape. Well-edged crystals of pyramidal-prismatic outlook (more than $16 \mathrm{~cm}$ long, 3-4 cm thick) are frequent. They are simple and geniculated twins of dark-brown colour. They differ from black casserites of Kalba pegmatite deposits by low tantalum content $\left(\mathrm{Ta}_{2} \mathrm{O}_{5}\right.$ from 0.003 up to $\left.0.03 \%\right)$ and by parameters of crystal lattice $\left(a_{0}=4.7358, c_{0}=3.1836\right)$. Chemical composition (\%): $\mathrm{SiO}_{2}-0.66, \mathrm{TiO}_{2}-0.54, \mathrm{Al}_{2} \mathrm{O}_{3}-$ $0.03, \mathrm{Fe}_{2} \mathrm{O}_{3}-0.13, \mathrm{CaO}-0.11, \mathrm{~W}_{3}-0.18, \mathrm{Sn}-97.74, \mathrm{Ta}_{2} \mathrm{O}_{5}-$ 0.03 , n.n.n. -0.51 , sum 99.93. Impurity elements: Ta, Nb, W, Mo and rare alkalies, as well as In and $\mathrm{Ag}$ (Table 2).

Microinclusions of native stannum ( $\mathrm{Sn}-100$ weight \%) and pure casserite ( $\mathrm{Sn}-77.37$ and $0-22.63$ weight $\%$ ) are detected in ores on SEM-images. Besides, impurities are observed in other samples: Ti (12.60), W (8.75), As (10.37) and $\mathrm{Sr}, \mathrm{Br}, \mathrm{P}$ (up to 1-2 weight \%) are in small amount. Ta content in casserite is low (1.22 weight \%) (Fig. 4).

Geological-genetic model of deposit formation is represented by contact action of Narym granitoid massif on older dykelike bodies of plagiogranites and occurrence of fissure- ruptural deformation and contact-metasomatic transformations (gneiss metamorphosis, graphitization, greysening, silicification), and ore substance deposition ( $\mathrm{Sn}, \mathrm{W}, \mathrm{Be}, \mathrm{As}$, and others). Ore deposition included ore caused components ( $\mathrm{Sn}, \mathrm{W}$, $\mathrm{B}, \mathrm{F}, \mathrm{H}_{2} \mathrm{O}$ ), that are gained by fluid flows of Kalba granite when there is counter migration of elements from enclosing sedimentary rocks and plagiogranites $(\mathrm{Ca}, \mathrm{Mg}, \mathrm{Na}, \mathrm{C}$, and others). Plagiogranites with early large quartz veins represented peculiar fracture structural-lithological traps or geochemical barriers for concentration of stannum-tungsten ore.

Cherdoyak deposit is compared with well-known greisenquartz-veined deposits of Central Kazakhstan, Uzbekistan, the Far East, the Rudny mountains and other regions [12]. These deposits are Bainazar, Stepanovskoye, Uchkoshkom, Pravourmiyskoe, Krasno, Tsinovets, Altenberg and others. Common regularity for them is that stannum-tungsten ore is superimposed on older rocks due to intrusions of granite composition formed by several stages. Peculiarity of Cherdoyak is that it was formed within strictly limited space, in dyke-like body of plagiogranites. Sustainable quartz-turmaline-scheelite-arsenopyrite-cassiterite ore paragenesis, veined-stockwork morphology of ore bodies and prospecting data show that only the central part of ore-bearing zone is opened. Favorable position of plagiogranites in the exocontact of ore parent source (Kalba granites) also enables to suppose and forecast new ore-bearing quartz stockworks. So the deposit should be further studied. 
Content of rare and accompanying elements in casserites of Cherdoyak deposit $(\mathrm{g} / \mathrm{t})$

\begin{tabular}{|c|c|c|c|c|c|c|c|c|c|c|}
\hline Sample No. & $\mathrm{Ta}$ & $\mathrm{Nb}$ & $\mathrm{Be}$ & $\mathrm{Li}$ & $\mathrm{Rb}$ & $\mathrm{Cs}$ & $\mathrm{W}$ & $\mathrm{Mo}$ & $\mathrm{In}$ & $\mathrm{Ag}$ \\
\hline 4201 & 3.37 & 8.59 & 0.50 & 18.51 & 64.91 & 7.56 & 76.74 & 4.25 & 18.10 & 8.98 \\
\hline 5406 & 140.0 & 129.5 & 0.61 & 18.50 & 14.44 & 3.89 & 24.78 & 4.49 & 28.78 & 3.33 \\
\hline 5424 & 6.25 & 4.84 & 1.42 & 7.80 & 24.28 & 1.45 & 6.56 & 4.49 & 26.64 & 5.85 \\
\hline $5428 \mathrm{~A}$ & 30.58 & 14.36 & 0.40 & 50.54 & 169.77 & 41.52 & 121.2 & 4.52 & 82.96 & 4.10 \\
\hline \multicolumn{8}{|c|}{ Results of ICP-MS analyses } \\
\hline
\end{tabular}

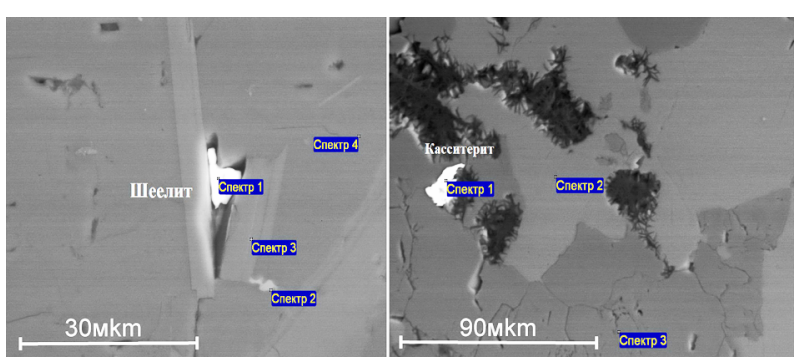

Fig. 4. Microinclusions of minerals in plagiogranites of Cherdoyak deposit

Results. The outcomes published in this article are a part of continuing research on fundamental problem of the Great Altai (geology and metallogeny) focused on strengthening and development of mineral-raw material base for metallurgical and mining enterprises. New results of the work on KalbaNarym zone prove that the scheme of granitoid magmatism, which has been developed before on materials of large-scale geological mapping, is practically confirmed by up-to-date geochronological data $[6,10]$.

Geological and genetic model of rare metal pegmatite forming in granitoids of Kalba complex $\left(\mathrm{P}_{1}\right)$ is compared with rare metal granite-pegmatite systems of normal alkalinity [7].

The rationale of plagiogranites role as favorable ore hosting environment for deposition and concentration of superimposed pegmatite ore (mainly with lithium spodumene ore) and practically significant greisen-quartz veined cassiterite-scheelite ores $(\mathrm{Sn}, \mathrm{W})$ is of special importance.

Model of ore genesis reflects contact-metasomatic transformation of plagiogranites under the action of the formed rare metal fluids of Kalba complex. Unconventional "extrapegmatite" type of rare metal ore includes albite-greisen metasomatites with $\mathrm{Sn}-\mathrm{Ta}-\mathrm{Li}$ specialization that have not been sufficiently explored (Novo-Akhmirovskoye, Karasu deposits). According to genesis, the considered objects are compared with well-known deposits (Alakh, Losevskoye) and recommended for further exploration. The conducted research studies contribute to understanding the processes of rare metal ore formation and are of applied significance.

Conclusions. Deposits of non-ferrous, precious and rare metals and other industrial minerals occur in East Kazakhstan of Central Asia. Common regularity is in their formation in different geodynamic environments in genetic connection with definite ore-magmatic systems and belt distribution of ore objects. The main types of rare metals deposits $(\mathrm{Ta}, \mathrm{Nb}, \mathrm{Be}, \mathrm{Li}$, $\mathrm{Cs}, \mathrm{Sn}, \mathrm{W}$ ) were formed during Hercynian cycle in post-collision (orogenic) geodynamic environment at Permian time.

The main industrial deposits of rare metal pegmatites are concentrated in the Kalba-Narym belt. The pegmatites have spatial-genetic relations with granites of Kalba complex $\mathrm{P}_{1}$ (Bakennoye, Yubileinoye, Belaya Gora and others). Rare metal ore of pegmatite type ( $\mathrm{Li}, \mathrm{Ta}, \mathrm{Be}, \mathrm{Sn})$ and of greisen-quartz-veined type $(\mathrm{Sn}, \mathrm{W})$ are of special significance. They are superimposed on the older hypabyssal minor intrusions and dykes of plagiogranite composition (Medvedka, Tochka, Cherdoyak, and others).
Plate-shaped bodies of plagiogranites are tectonically faulted and contact-metasomatically conversed. They are considered as favorable physical and chemical environments for deposition and concentration of ore substance in accordance with views of such researchers as G.N. Shcherba, S. F. Lugov, F. N. Shakhov, and others. Pegmatite deposits of this type with low content of Ta, Nb, $\mathrm{Be}$ are of great interest for lithium spodumene ore $[5,10]$.

Unconventional sources of stannum-tantalum-lithium ore of "extra-pegmatite" type are connected with ore-bearing albitized and greisenized granites that crop out (NovoAkhmirovskoye, Alakha, Apogranitnoye, and so on), and concealed at the depth (Karasu, Malo-Chernovinskoye, Shuruk). They are recommended for further exploration. The conducted research studies prove that there are additional reserves in the explored regions for strengthening raw material base of rare metal production. Resumption of prospecting and deeper exploration of ore-bearing structures and ore objects are required.

The work was completed with the financial support of Science Committee of RK Ministry of education and science APO5131489, AP 08052707.

\section{References.}

1. Annikova, I. Yu., Vladimirov, A. G., Smirnov, S. Z., \& Gavryushkina, O.A. (2016). Geology and mineralogy of the Alakha Spodumene Granite Porphyry Deposit, Gorny Altai, Russia. Geology of Ore Deposits, 58(5), 404-426. https://doi. org/10.1134/S1075701516050020.

2. Khromykh, S.V., Sokolova, E.N., Smirnov, S.Z., Travin, A. V., \& Annikova, I. Yu. (2014). Geochemistry and age of rare metal dyke belts of East Kazakhstan. Doklady akademii nauk, Rossiyskaya akademiya nauk, 459(5), 612-617 https:// doi.org/10.7868/S086956521435019.

3. D'yachkov, B.A., Kuz'mina, O. N., Rafailovich, M.S., \& Oytseva, T.A. (2014). Geodynamic settings of gold and rare metal deposit formation in East Kazakhstan. Blagorodnye, redkie i radioaktivnye elementy $v$ rudoobrazuyushchikh sistemakh/ Materialy Vserossiyskoy nauchnoy konferentsii. Novosibirsk: INGG SO RAN, 348-354.

4. Mizernaya, M.A., Aitbayeva, S. S., Mizerny, A. I., Dyachkov, B.A., \& Miroshnikova, A. P. (2020). Geochemical characteristics and metalogeny of Herzin granitoid complexes (Eastern Kazakhstan). Naukovyi Visnyk Natsionalnoho Hirnychoho Universytetu, Ukraine, (1), 5-10. https://doi. org/10.33271/nvngu/2020-1/005.

5. Khromykh, S. V., Tsygankov, A.A., Kotler, P. D., Navozov, O. V., Kruk, N. N., Vladimirov, A. G., Travin, A. V., ..., \& Karavaeva, G. S. (2016). Late Paleozoic granitoid magmatism of Eastern Kazakhstan and Western Transbaikalia: Plume model test. Russian Geology and Geophysics, 57(5), 773-789. https://doi.org/10.1016/i.rgg.2015.09.018.

6. Beskin, S. M., \& Marin, Yu. B. (2017). On the classification of pegmatite-bearing granite systems. Materialy III mezhdunarodnoi geologicheskoi konferentsii. Ekaterinburg: IGG UrO RAN, 40-42. 7. Kotler, P.D., Khromykh, S.V., Vladimirov, A. G., Navozov, O.V., \& Murzintsev, N.G. (2015). New data on the age and geodynamic interpretation of the Kalba-Narym granitic batholith, eastern Kazakhstan. Doklady Earth Sciences, 462(2), 565-569. https://doi.org/10.1134/S1028334X15060136. 
8. Beskin, S. M., \& Marin, Yu. B. (2019). Peculiarities of granite systems with rare metal pegmatites. Zapiski Rossiyskogo mineralogicheskogo obshchestva, 148(4), 1-16. https://doi. org/10.30695/zrmo/2019.1484.00.

9. Dittrich, T., Seifert, T., Schulz, B., Hagemann, S., Gerdes, A., \& Pfänder, J. (2019). Archean Rare-Metal Pegmatites in Zimbabwe and Western Australia. Geology and Metallogeny of Pollucite Mineralisations. Springer International Publishing, 134. https://doi.org/10.1007/978-3-030-10943-1.

10. Sun LiQiang, Ling HongFei, \& Zhao KuiDong (2017). Petrogenesis of Early Cretaceous adakitic granodiorite: Implication for a crust thickening event within the Cathaysia Block, South China. Science China. Earth Sciences, 60(7), 1237-1255. https://doi.org/10.1007/s11430-016-5200-y.

11. Kholgh, M., Razmara, M., \& Arian, M. (2017). Petrogenesis and Metallogenesis of Malek Siah Kuh Adakite-Like Rocks and Associated Hydrothermal Mineralization (Sistan Area, Iran). Open Journal of Geology, 7, 1670-1689. https:// doi.org/10.4236/ojg.2017.711112.

12. Gusev, N. I., \& Fedak. S. I. (2014). Buried granitoids of the Kalba belt in the Russian Southwest Altai: material composition, geochemistry, geochronology. Geologiya i mineral'nosyr'yevye resursy Sibiri, 1(4(20)), 91-103.

13. Lavrik, S. N., \& Chashchin, A. A. (2018). Adakites of Primorye: material compositions of a possible source of andesitic magmas, physicochemical conditions and geodynamic conditions of their generation. Volyntsovskie chteniya: materialy I Vseros. konf. po petrologii i geokhimii zon perekhoda "okeankontinent”, posvyashch. pamyati O.N. Volyntsa. PetropavlovskKamchatskiy. IViS DVO RAN, 47-48.

14. Potseluev, A. A. (2014). Precious metals ore in hydrothermal uranium and rare metal deposits of Central Asia: monograph. Tomsk: STT.

15. Rafailovich, M. S. (2013). Geology of Central Asian gold: ore evolution, metasomatic formations, explosive breccia: monograph. Almaty. ISBN978-601-289-107-2.

\section{Нові дані про нетрадиційні типи рідкометального зруденіння Східного Казахстану}

\section{Б. О. Д'ячков ${ }^{1}$, С. С. Айтбаєва ${ }^{2}$, М. О. Мізерна ${ }^{2}$, Б. Б. Амралінова ${ }^{2}$, А. Е. Бісатова ${ }^{3}$}

1 - ТОВ «Алтайський геолого-екологічний інститут», м. Усть-Каменогорськ, Республіка Казахстан, е-mail: bdyachkov@mail.ru

2 - Східно-Казахстанський державний технічний університет імені Д. Серікбаєва, м. Усть-Каменогорськ, Республіка Казахстан, e-mail: AitbayevaSS@mail.ru 3 - ТОВ «ГЕОС», м. Усть-Каменогорськ, Республіка Казахстан

Мета. Вивчення закономірностей формування та оцінка перспектив нетрадиційних типів рідкометального зруденіння Східного Казахстану.

Методика. Аналіз літературних і фондових матеріалів; проведення польових досліджень на типових об'єктах; відбір проб; виконання ізотопних досліджень на типових об'єктах; мас-спектрометричний аналіз на спектрометрі ICP-MS-Agilent 7500cx, мікрозондовий аналіз за допомогою скануючого електронного мікроскопа JSM 6390LV з енергодисперсійною приставкою, рентгеноструктурний аналіз - СРВ-1М, силікатний хімічний аналіз.

Результати. Обгрунтовано виділення нового нетрадиційного «внепегматитового» типу рідкометального зруденіння переважно літієвої спеціалізації, що асоціюється з малими інтрузіями й дайками кунушского комплексу та альбітизованими та грейзенізованими гранітами (апогранітами).
Наукова новина. Розроблена геолого-генетична модель рідкометального рудоутворення, що відображає накладення різних металів (Sn, W, Li та ін.) на більш ранні малі інтрузії плагігранітів кунушского комплексу $\left(\mathrm{C}_{3}\right)$, схильних до контактово-метасоматичних перетворень під впливом рідкометальних гранітів калбінського комплексу $\left(\mathrm{P}_{1}\right)$. Обгрунтовані перспективи самостійного «внепегматитового» типу олово-тантал-літієвого зруденіння.

Практична значимість. Результати дослідження спрямовані на зміцнення мінерально-сировинної бази в якості додаткового джерела рідких металів для діючих підприємств Східного Казахстану.

Ключові слова: Східний Казахстан, гранітоїдні пояса, адакіти, родовища, рідкі метали, Калба-Наримська зона

\section{Новые данные о нетрадиционных типах редкометалльного оруденения Восточного Казахстана}

\author{
Б.А.Дьячков ${ }^{1}$, С. С. Айтбаева ${ }^{2}$, М.А. Мизерная ${ }^{2}$, \\ Б. Б. Амралинова ${ }^{2}$, А. Е. Бисатова ${ }^{3}$
}

1 - ТОО «Алтайский геолого-экологический институт», г. Усть-Каменогорск, Республика Казахстан; e-mail: bdyachkov@mail.ru

2 - Восточно-Казахстанский государственный технический университет имени Д. Серикбаева, г. УстьКаменогорск, Республика Казахстан; e-mail:AitbayevaSS@ mail.ru

3 - ТОО «ГЕОС», г. Усть-Каменогорск, Республика Казахстан

Цель. Изучение закономерностей формирования и оценка перспектив нетрадиционных типов редкометалльного орудунения Восточного Казахстана.

Методика. Анализ литературных и фондовых материалов; првоведение полевых исследований на типовых объектах; отбор проб; выполнение изотопных исследований на типовых объектах; масс-спектрометрический анализ ICP-MS-Agilent $7500 \mathrm{cx}$, микрозондовый анализ с помощью сканирующего электронного микроскопа JSM 6390LV с энергодисперсионной приставкой, рентгеноструктурный анализ - CРВ-1M, силикатный химический анализ.

Результаты. Обосновано выделение нетрадиционного «внепегматитового» типа редкометалльного оруденения преимущественно литиевой специализации, ассоциирующего с малыми интрузиями и дайками кунушского комплекса и альбитизированными и грейзенизированными гранитами (апогранитами).

Научная новизна. Разработана геолого-генетическая модель редкометалльного рудообразования, отражающая наложение редких металлов (Sn, W, Li и др.) на более ранние малые интрузии плагигранитов кунушского комплекса $\left(\mathrm{C}_{3}\right)$, подверженных контактово-метасоматическим преобразованиям под влиянием редкометалльных гранитов калбинского комплекса $\left(\mathrm{P}_{1}\right)$. Обоснованы перспективы самостоятельного «внепегматитового» типа олово-тантал-литиевого оруденения.

Практическая значимость. Результаты исследования направлены на укрепление минерально-сырьевой базы в качестве дополнительного источника редких металлов для действующих предприятий Восточного Казахстана.

Ключевые слова: Восточный Казахстан, гранитоидные пояса, адакиты, месторождения, редкие металлы, КалбаНарымская зона

Recommended for publication by Ye. M. Sapargaliyev, Doctor of Geological and Mineralogical Sciences. The manuscript was submitted 24.11.19. 